\title{
Seedling establishment characteristics of alternative legume species in tussock grassland environments
}

W.L. LOWTHER AND HEATHER N. PATRICK Invermay Agricultural Centre, AgResearch, Private Bag, Mosgiel

\begin{abstract}
Four altemative legume species, Caucasian clover (Trifolium ambiguum), zigzag clover (T. medium), crown vetch (Coronilla varia), and birdsfoot trefoil (Lotus corniculatus), were compared with white clover (T. repens) on four tussock grassland sites. Seed was inoculated and pelleted, and then over. sown at a rate equivalent to $5 \mathrm{~kg} / \mathrm{ha}$ viable seed. Germination, nodulation and survival of white clover, Monaro Caucasian clover, and zigzag clover were similar on the two lowest sites (600 and $830 \mathrm{~m})$. However, low rates of zigzag clover germination occurred on the two higher sites (1090 and $1100 \mathrm{~m}$ ). Germination of crown vetch appeared to be prevented or delayed by the low temperatures, and no plants established on any site. Low nodulation occurred in Treeline Caucasian clover and birdsfoot trefoil. Further research is required to select more suitable strains of rhizobia for both these legumes. The results provide information for estimating likely plant densities of these new cultivars when oversown in tussock grassland environments.
\end{abstract}

Keywords Coronilla varia, establishment, germination, inoculation, Lotus corniculatus, nodulation, Trifoliumambiguum, Trifolium medium, Trifolium repens

\section{Introduction}

Limitations in the suitability of conventional legume species for some areas of the tussock grasslands have been identified by Allan (1985). In a survey on Tara Hills. Allan \& Chapman (1987) reported that white clover (Trifolium repens) was the most successful clover but it had not persisted on sunny faces. Red clover (7'. pratense) and alsike clover (T. hybridwn) had not persisted in intensively managed swards. Caucasian clover (T. ambiguum), zigzag clover (T. medium), crown vetch (Coronilla varia) and birdsfoot trefoil (Lotus corniculatus) are legumes suggested as having potential for tussock grassland environments (Keoghan 1985; Scott \& Charlton 1983). However. most of the work investigating these species has been carried out with small plot trials, sometimes with transplanted spaced plants. Little information is available on establishment of these new cultivars. In fact, Lucas et al. (1981) reported sparse establishment of Caucasian clover in contrast to white clover.

The aim of the present experiment was to obtain information on the germination, nodulation and establishment of these alternative legume species, compared with white clover, on a range of sites in the Otago tussock grasslands.

\section{Materials and methods}

Seed of Caucasian clover (cvs Monaro and Treeline), zigzag clover (G41), crown vetch (G32), and white clover (cv Grasslands Huia) was inoculated with peat based inoculants at a high rate $(30 \mathrm{~g}$ peat per $\mathrm{kg}$ seed) and pelleted using $40 \%$ gum arabic as the adhesive and microfine lime as a coating material. Birdsfoot trefoil (cv Maitland) seed was inoculated and coated by Coated Seed Ltd. Strains of rhizobia used were ICMP 4073b for Monaro Caucasian clover. 4074b for Treeline Cauca-

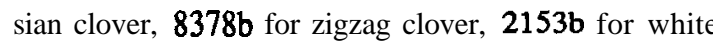
clover, 5058 for crown vetch and SU 343 for birdsfoot trefoil.

Species were oversown. at a rate equivalent to $5 \mathrm{~kg} /$ ha viable bare seed, on four undeveloped tussock grassland sites in the Mackenzie Basin and Central Otago in mid-September 1990. The species were randomised in four replicate blocks on each site. The Berwen-low site was on a yellow-grey earth soil with a $\mathrm{pH}$ (1:2.5 soil:water) of 5.9 at an altitude of $830 \mathrm{~m}$. There was a thick vegetative cover of snow tussock (Chionochloa rigida), fescue tussock (Festuca novae-zelandiae). browntop (Agrostis capillaris), a native plant understorey and $20 \%$ bareground. The Berwen-mid site was on a yellowbrown earth soil with a pH of 5.6 at an altitude of 1090 $\mathrm{m}$. The vegetation was similar to the low site but more sparse with $40 \%$ bare ground. The Tara site was on a YBE soil with a $\mathrm{pH}$ of 5.2 at an altitude of $1100 \mathrm{~m}$. The predominate vegetation was snow tussock with $65 \%$ bare ground. The Eamscleugh site was on a brown-grey earth with a $\mathrm{pH}$ of 5.9 at an altitude of $600 \mathrm{~m}$. The dominant vegetation cover consisted of fescue tussock, silver tussock (Poa caespitosa), hair grass (Vulpia bromoides) and $45 \%$ bare ground. A basal dressing of 200 
$\mathrm{kg} / \mathrm{ha}$ of molybdic-sulphur-superphosphate $(0.01 \%$ Mo; $8 \%$ P; $19 \%$ S) was applied before sowing. Seed was oversown onto the undisturbed soil surface at all sites. However, on the semi-arid Eamscleugh site, seed was lightly raked into the soil surface to duplicate the effect of stock trampling in improving seed:soil contact (Allan et al. 1987). Miral (20 kg/ ha) was applied prior to seed germination to reduce insect damage, particularly from broad nosed weevils (Barratt \& Johnstone 1984). With large scale sowings insect damage can be reduced by applying insecticide to the seed coating.

The numbers of rhizobia on the seed at sowing were estimated by plate counts (Vincent 1970). Seed germination/ early seedling establishment was assessed by quadrat counts when seedlings reached the cotyledon/ unifoliate stage (6-10 weeks after sowing) and results have been expressed as a percentage of viable seed sown. At the same time, 20 seedlings in each plot were pegged with wire markers and the percentage of nodulated plants was recorded 17-21 weeks after sowing. Survival of pegged seedlings was assessed 8 and 14 months after sowing. Percentage seed germination at each site was analysed by analysis of variance according to the randomised block design. Seedling nodulation and survival out of 20 plants per plot at each site was analysed as a generalised linear model with binomial error distribution, fitting terms for block and species and calculating effective standard errors on the back transformed scale.

\section{Results and discussion}

\section{Populations of rhizobia}

Clovers and crown vetch had in excess of 3000 rhizobia per seed at sowing. These populations are higher than those shown to be necessary for the nodulation of white clover on a range of tussock grassland sites (Lowther 1977). The commercially pelleted biidsfoot trefoil contained 1100 rhizobia per seed at sowing, well in excess of the 300 per seed considered as the minimum standard for commercially pelleted white clover seed by the Inoculant and Coated Seed Testing Service (Johnson 1979).

\section{Germination and early seedling establishment}

The percentages of seed germinating and reaching the cotyledon stage (germination) varied over the four sites (Table 1).

No crown vetch seedlings were found on the Berwen and Tara sites 6-8 weeks after sowing and there were only a low number at Earnscleugh after 10 weeks. Some crown vetch seedlings ( $<1$ per $\mathrm{m}^{2}$ ) were present on the Berwen-low site 17 weeks after sowing, indicating that
Table 1 Percentage of seeds geminating and reaching cotyledon stage, 6-10 weeks after sowing, relative to number of viable seed sown

\begin{tabular}{lcccc}
\hline & Berwen-low & Berwen-mid & Tara Hills & Earnsdeugh \\
\hline white & 14 & 25 & 31 & 22 \\
Monaro' & 10 & 18 & 40 & 31 \\
Treoline' & 13 & 15 & 43 & 40 \\
Zlgzag & 10 & 5 & 14 & 24 \\
Birdsfoot & 13 & 12 & 22 & 17 \\
Crown vetch & 0 & 0 & 0 & 11 \\
SED & 4.8 & 4.6 & 7.1 & 10.8 \\
\hline
\end{tabular}

1 Caucasian clover

limited germination had occurred later in spring. Controlled environment studies have shown that crown vetch is not only slow to commence germination at optimum temperatures but also requires higher temperatures for germination than conventional dover species (Hill \& Luck 1991). For example. the calculated base temperature for crown vetch (cv Chemung) germination was $6.9^{\circ} \mathrm{C}$, compared with $5.8^{\circ}, 5.2^{\circ}$ and $4.8^{\circ} \mathrm{C}$ for white clover (cv Haifa), Caucasian clover (cv Monaro) and birdsfoot trefoil (cv Dewey) respectively. Hill \& Luck (1991) conduded that crown vetch germplasm needs to be screened for better germination at low temperatures to be useful in temperate climates particularly when germination is required in early spring. This condusion is supported by the present data.

There were no consistent differences in germination between the other species. However, there was a consistent trend for low germination from zigzag dover on the two highest sites.

Low rates of seed germination and early seedling establishment are major problems under oversowing conditions, particularly in drier environments, and trampling by stock hooves to improve seed:soil contact is well recognised as a means of improving establishment (Allanet al. 1987). However, the technique is not widely practised in the tussock grasslands because of the difficulty of obtaining sufficient stock in early spring to shepherd around oversown blocks. Similar germination rates to those obtained in the present study can therefore be expected when oversowing in the tussock grasslands.

\section{Nodulatlon}

Nonodulated seedlings were recorded in crown vetch on any site. Few healthy seedlings of any species were presentonthedry Earnscleughsitedue to the early onset of moisture stress. 
Table 2 Percentage of seedlings that were nodulated, 17-21 weeks after sowing

Berwen-low Berwen-mid Tara Hills Earnscleugh

\begin{tabular}{lcccc}
\hline White & 50 & 35 & 25 & 9 \\
Monaro' & 44 & 46 & 43 & 6 \\
Treeline' & 15 & 19 & 14 & 0 \\
Zigzag & 46 & 46 & 26 & 6 \\
Birdsfoot & 4 & 1 & $\mathbf{5}$ & $\mathbf{0}$ \\
Crown vetch & nd² $^{2}$ & nd & nd & $\mathbf{0}^{\mathbf{s}}$
\end{tabular}

${ }^{1}$ Caucasian clover

2 No data

3 Not included In the statistical analysis

4 Effective s.e. for differences from white dover

There was a virtual nodulation failure in birdsfoot trefoil on all sites. The commercially pelleted seed contained 1100 rhizobiaper seed at sowing, a number in excess of the standard for commercial pelleted seed in New Zealand (Johnson 1979). However, recent work (Patrick \& Lowther 1993), has shown that even populations as high as 23000 rhizobia per seed are not sufficient to ensure nodulation of biidsfoot trefoil oversown onto difficult tussock grassland sites. Further research, in cooperation with commercial fiis, is underway to alleviate the problem.

Seedling nodulation was low in Treeline Caucasian clover on all sites. Caucasian clover is very specific in Rhizobium requirements and strains effective on white clover do not form nodules or are ineffective on Caucasian clover (Parker \& Allen 1952). In addition, different strains of rhizobia arc required for tctraploid (eg Treeline) and hexaploid (eg Monaro) cultivars. The strains used for inoculation in the present study had been recommended after evaluation of nodulation and symbiotic effectiveness under controlled conditions. Selection of rhizobia for nodulating ability under oversowing conditions appears necessary to improve establishment of Treeline Caucasian clover.

Inoculation was carried out under laboratory conditions using a rate of peat inoculant $(30 \mathrm{~g}$ per $\mathrm{kg}$ seed), higher than the rate (6.4-19 g) stipulated on commercial inoculants, to test the effectiveness of the strains of rhizobia. Further research is underway to define minimum populations of rhizobia needed for satisfactory nodulation of oversown Monaro Caucasian clover.

\section{Survival}

On the two Berwen sites, survival in autumn (Table 3) and the following spring (Table 4) was closely related to the percentage of seedlings nodulated (Table 2). However, at Tara Hills, the majority of nodulated Caucasian clover and zigzag clover seedlings failed to survive. Due to the early onset of snow, the autumn assessment was not carried out at Tara Hills but visual observations indicated that there was a severe loss of seedlings over the summer due to moisture stress.

Table 3 Percentage plant survival 8 months after sowing, relative to initial seedlings established

\begin{tabular}{|c|c|c|c|c|c|c|}
\hline & & lerwen & low & Berwen mid & Tara Hills & Earnscleugh \\
\hline White & & 61 & & 46 & $n d^{2}$ & 5 \\
\hline Monaro' & & 31 & & 55 & nd & 6 \\
\hline Treeline ${ }^{1}$ & & 11 & & 26 & nd & 21 \\
\hline Zigzag & & 54 & & 40 & nd & 6 \\
\hline Birdsfoot & & 6 & & 3 & nd & 3 \\
\hline Crown & vetch & nd & & nd & nd & $0^{3}$ \\
\hline SED 4 & & 6.1 & & 6.0 & & 3.8 \\
\hline
\end{tabular}

1 Caucasian dover

2 No data

3 Not included In statistical analysis

- Effective s.e. for differences from white dover

Table 4 Percentage plant survival 14 months after sowing. relative to initial seedlings established

\begin{tabular}{|c|c|c|c|c|}
\hline & Berwen-low & Berwen-mid & Tara Hills & Earnsdeugh \\
\hline white & 61 & 46 & 20 & 9 \\
\hline Monaro' & 35 & 59 & 14 & 4 \\
\hline Treeline' & 14 & 29 & 4 & 14 \\
\hline Zlgzag & 51 & 41 & 8 & 6 \\
\hline Birdsfoot & 6 & 3 & 0 & 0 \\
\hline Crown vetch & $h n d^{2}$ & nd & nd & $0^{3}$ \\
\hline SED 4 & 8.1 & 6.2 & 5.5 & 4.5 \\
\hline
\end{tabular}

1 Caucasian clover

2 No dam

3 Not included in statistical analysis

4 Effective s.e. for differences from white clover 


\section{Conclusions}

The present results have important implications for the choice of alternative pasture legumes. The legumes used in the present study have all been suggested as having potential for the tussock grassland (Keoghan 1985). However, it is clear that problems withboth germination and seedling survival have the potential to limit the success of some of the cultivars.

The most important features of the results are :-

1. Crown vetch is unlikely to have a place for oversowing in the tussock grasslands because germination limitations and slow seedling growth under low spring temperatures are likely to prevent establishment.

2. Monaro Caucasian clover appears to have similar germination and nodulation characteristics to white clover indicating its suitability for oversowing.

3. Further research is required to select amore suitable strain of rhizobia for Treeline Caucasian clover and birdsfoot trefoil to improve nodulation and hence establishmentunderoversowing.

4. Zigzagcloveris similar to white clover in germination and nodulation at lower altitudes but germination appears to be restricted at higher elevations.

\section{ACKNOWLEDGEMENTS}

Grasslands Division, DSIR, Palmerston North for supply of seed; Coated Seed Ltd., Christchurch for commercial coating of seed; Mr Alistair Campbell, Earnscleugh Station and Mr Dick Croft, Berwen Station for use of land.

\section{REFERENCES}

Allan, B.E. 1985. Pasture species most suited to nonarable hill and high country: A new look at traditional species. Proceedings of the 1985 Hill andHigh Country Seminar. Centrefor Resource Management, Special Publication No. 4, Lincoln College:39-44.

Allan, B.E.; Chapman H.M. 1987. Oversown tussock country: Lessons from 30 years of improvement and management on Tara Hills. Proceedings of the NZ Grassland Association 48:77-81.

Allan, B.E; Lowther. W.L.; Walton P.J. 1987. Pastures. High country. Planning, establishment. management of oversown grasses and clover-s. Aglink FPP 886. MAF, Wellington.
Barratt, B.I.P.; Johnstone, P.D. 1984. Effectsof insects, seeding rate, and insecticide seed dressing on white clover and Maku lotus in tussock grassland. NZ journal of agricultural research 27:1318.

Hill, M.J.; Luck, R. 1991. The effect of temperature on germination and seedling growth of temperate perennial pasture legumes. Australian journal of agricultural research 42: 175189.

Johnson, D. 1979. Legumes. Seed inoculation. An introduction.AglinkFPP314. MAF, Wellington

Keoghan, J.M. 1985. Fitting pasture species and cultivars into high country landscapes and grazing systems. Proceedings of the 1985 Hill andHigh Country Seminar. Centrefor Resource Management, Special Publication No. 4, Lincoln College: 51-57.

Lowther, W.L 1977. Factors affecting the response of clover establishment to inoculation and pelleting. Proceedings of the NZ Grassland Association 38(1): 175-181.

Lucas, R.J.; White. J.G.H.; Daly, G.T.; Jarvis, P.; Meijer, G. 1981: Lotus, white clover and Caucasian clover oversowing, Mesopotamia Station, South Canterbury. Proceedings of the NZ Grassland Association 42:142-151.

Parker, D.T.; Allen. O.N. 1952. The nodulation status of Trifoliwn ambiguum. Proceedings of the Soil Science Society of America 16:350-353.

Patrick, H.N.; Lowther. W.L. 1993. Response of Lotus corniculatus to inoculation and pelleting on a range of Otago tussock grassland environments. Proceedings of the NZ Grassland Association 54: In press

Scott, D.; Charlton. J.F.L. 1983. Birdsfoot trefoil (Lotus corniculatus) as a potential dryland herbage legume in New Zealand. Proceedings of the NZ Grassland Association 44:98-105.

Vincent, J.M. 1970: A manual for the practical study of root-nodule bacteria. IBP Handbook No 15 . Blackwells Scientific Publishing, Oxford. 